\title{
Menelisik Penerimaan e-faktur versi 3.0 Melalui Pendekatan Technology Acceptance Model
}

Ni Putu Ariasih ${ }^{1}$, Luh Putu Mahyuni², Anak Agung Made Sastrawan Putra ${ }^{3}$

1Universitas Terbuka, UPBJJ UT Denpasar, Bali

2Universitas Pendidikan Nasional, Denpasar, Bali

3Universitas Terbuka, Jakarta

\section{ARTICLE INFO}

\section{JEL Classification:} H21, $\mathrm{H} 26$

Key words:

e-invoice version 3.0, Technology Acceptance Model (TAM), perceived usability, perceived convenience.

\begin{abstract}
The e-invoice 3.0 application was just introduced on October 1, 2020. Taxable employer (PKP) acceptance of e-invoice 3.0 is very important for the effectiveness tax reporting and revenue. The Technology Acceptance Model (TAM) is employed as a theoretical framework that guides process of data collection and analysis. Qualitative approach through in-depth interviews was carried out to PKP which is e-invoice 3.0 pilot project at the North Badung Primary Tax Office, Bali. Data were analyzed using coding and themeing technique. This study indicates that PKP has a good acceptance of the einvoice 3.0 application. The perceptions of usefulness identified are: accelerating work, increasing performance, increasing productivity, effectiveness, making work easier, useful in monitoring data. Meanwhile, the perceptions ease of use identified are: easy to learn, controllable, clear and understandable, flexible, easy to master, easy to use, constraints quickly resolved, and intensity of use. Perceptions of usefulness and perceived ease of use can explain user attitudes and interest in using the e-invoice 3.0 application. A model that explains the acceptance of a new technology, particularly einvoicing 3.0, is offered in this study. Some suggestions for policy makers are also provided to further improve the e-invoicing 3.0 application.
\end{abstract}

\begin{abstract}
ABSTRAK
Aplikasi e-faktur versi 3.0 baru saja diperkenalkan tanggal 1 Oktober 2020. Penerimaan pengusaha kena pajak (PKP) atas e-faktur versi 3.0 sangatlah penting untuk efektivitas pelaporan dan penerimaan pajak. Technology Acceptance Model (TAM) digunakan sebagai kerangka teori yang memandu proses pengumpulan dan analisis data. Pendekatan kualitatif melalui wawancara mendalam dilakukan terhadap PKP pilot projecting aplikasi e-faktur versi 3.0 di Kantor Pelayanan Pajak Pratama Badung Utara, Bali. Data dianalisis dengan teknik coding dan themeing. Penelitian ini mengindikasikan bahwa PKP memiliki penerimaan yang baik atas aplikasi e-faktur versi 3.0. Persepsi kegunaan yang dijelaskan adalah: mempercepat pekerjaan, meningkatkan performa, meningkatkan produktifitas, efektifitas, mempermudah pekerjaan, bermanfaat dan monitoring data. Sementara persepsi kemudahan yang diidentifikasi adalah: mudah dipelajari, dapat dikontrol, jelas dan dapat dipahami, fleksibel, mudah mahir, mudah digunakan, kendala cepat teratasi, dan intensitas pemakaian. Persepsi kegunaan dan persepsi kemudahan dapat menjelaskan sikap pengguna dan minat penggunaan aplikasi e-faktur versi 3.0. Sebuah model yang menjelaskan penerimaan akan teknologi baru, khususnya e-faktur versi 3.0, ditawarkan penelitian ini. Beberapa saran bagi pengambil kebijakan juga diberikan untuk dapat lebih jauh menyempurnakan aplikasi efaktur versi 3.0.
\end{abstract}

\footnotetext{
*E-mail korespondensi: ${ }^{1}$ ni.putuariasih@gmail.com
} 


\section{PENDAHULUAN}

Direktorat Jenderal Pajak (DJP) berupaya untuk meningkatkan penerimaan negara dalam sektor perpajakan. Program modernisasi sistem perpajakan di implementasikan untuk meningkatkan kualitas pelayanan perpajakan. Salah satu modernisasi sistem perpajakan yang dilakukan DJP adalah aplikasi e-faktur versi 3.0. yang di implementasikan pada tanggal 1 Oktober 2020.

Pemberlakuan $e$-faktur versi 3.0 merupakan kelanjutan pembenahan administrasi Pajak Pertambahan Nilai oleh DJP. Fitur terbaru yang ada di e-faktur versi 3.0 adalah prepopulated. Menu prepopulated meliputi prepopulated pajak masukan maupun prepopulated Pemberitahuan Impor Barang (PIB).

Pada aplikasi e-faktur versi 3.0 yang berbasis web, data Pajak Masukan yang dapat wajib pajak kreditkan akan di-generate secara sistem. Hal ini dilakukan agar dapat meminimalisir kesalahan saat input data secara manual. Wajib pajak tidak perlu lagi melakukan input pajak masukan ke aplikasi efaktur versi 3.0.

Penelitian ini bertujuan menganalisis penerimaan aplikasi e-faktur versi 3.0 menggunakan TAM. Penelitian ini merupakan penelitian yang baru pertama kali diterapkan di KPP Pratama Badung Utara dengan Pengusaha Kena Pajak yang merupakan pilot projecting aplikasi e-faktur versi 3.0. Aplikasi e-faktur versi 3.0 diperkenalkan untuk mengatasi kelemahan e-faktur versi 1.0 dan 2.0. Untuk mengetahui keefektifan penerapan aplikasi efaktur versi 3.0 ini maka perlu dilakukan suatu penelitian melalui pendekatan TAM.

Pertanyaan penelitian ini adalah: 1 . Bagaimana penerimaan aplikasi e-faktur versi 3.0 melalui pendekatan TAM menggunakan konstruk persepsi kegunaan di KPP Pratama Badung Utara. 2. Bagaimana penerimaan aplikasi e-faktur versi 3.0 melalui pendekatan TAM menggunakan konstruk persepsi kemudahan di KPP Pratama Badung Utara. 3.Bagaimana persepsi kegunaan dan persepsi kemudahan dapat menjelaskan sikap terhadap penggunaan aplikasi e-faktur versi 3.0. 4. Bagaimana sikap terhadap penggunaan dapat menjelaskan minat penggunaan aplikasi efaktur versi 3.0.

Penelitian ini diharapkan dapat mengisi gap dalam literatur terkait hal yang dapat menjelaskan penerimaan atas teknologi baru umumnya, dan penerimaan atas e-faktur versi 3.0 khususnya. Temuan penelitian ini diharapkan dapat pula dijadikan referensi berharga bagi DJP untuk lebih jauh menyempurnakan aplikasi e-faktur versi 3.0, maupun untuk merumuskan kebijakan yang dapat meningkatkan penerimaan PKP atas aplikasi baru terkait perpajakan.

\section{TELAAH TEORI PENGEMBANGAN HIPOTESIS}

Technology Acceptance Model (TAM) dicetuskan oleh Davis pada tahun 1989. Ketika pengguna dihadapkan dengan teknologi baru, terdapat beberapa faktor yang mempengaruhi keputusan pengguna mengenai bagaimana dan kapan akan menggunakan teknologi baru (Soneka \& Phiri, 2019). TAM mengasumsikan peran mediasi dari dua variabel yakni persepsi kegunaan dan persepsi kemudahan (Granić \& Marangunić, 2019). TAM dapat memodelkan bahwa persepsi kegunaan dan persepsi kemudahan adalah penentu utama sikap individu terhadap penggunaan teknologi tertentu, yang pada gilirannya mempengaruhi niat untuk menggunakan suatu teknologi (Chen et al., 2017). TAM telah digunakan secara luas dalam berbagai studi untuk menggambarkan hubungan antara sikap dan niat (Ma et al., 2017).

Persepsi kegunaan adalah derajat yang diyakini seseorang bahwa menggunakan sistem tertentu akan meningkatkan kinerja pekerjaannya (Soneka \& Phiri, 2019). Persepsi kemudahan didefinisikan sebagai seberapa besar upaya yang dibutuhkan pengguna dalam menggunakan teknologi tertentu (Sangkaew et al., 2019). Sikap terhadap penggunaan adalah evaluasi positif atau negative perilaku pengguna (Kemp et al., 2019). Minat penggunaan (intention to use) adalah tingkat penerimaan pengguna untuk menggunakan suatu teknologi secara berkesinambungan (Natasya et al., 2019). 
Faktur pajak elektronik (e-faktur) adalah dokumen faktur pajak yang dihasilkan dari sistem elektronik Direktorat Jenderal Pajak (DJP). Tujuan diberlakukannya e-faktur adalah untuk meningkatkan kemudahan dan keamanan bagi PKP. Pada sistem aplikasi efaktur versi 3.0 ini, terdapat fitur tambahan yakni menu prepopulated. Menu prepopulated adalah menu yang menampilkan data Pajak Masukan yang dapat dikreditkan oleh PKP melalui sistem, tanpa input secara manual ke aplikasi e-faktur versi 3.0.

Terdapat beberapa penelitian terdahulu yang menggunakan TAM sebagai model untuk menjelaskan bagaimana penerimaan pengguna terhadap suatu sistem teknologi baru. Sikap pengguna sebenarnya dipengaruhi oleh persepsi kegunaan dan persepsi kemudahan penggunaan. Minat penggunaan dipengaruhi oleh sikap pengguna. Penelitian yang menemukan hal tersebut adalah (Bundot et al., 2017; Nguyen et al., 2020; Perangin-angin et al., 2016; Ratsidyaningtyas et al., 2016; Sijabat, 2020; Yasa et al., 2014). Terdapat penambahan persepsi kenyamanan untuk memprediksi tingkat kenyamanan yang dirasakan pengguna selama menggunakan layanan e-invoice (Bahari et al., 2020). Pada penelitian ini digunakan metode penelitian deskriptif kualitatif guna memperoleh informasi yang mendalam mengenai persepsi kegunaan dan persepsi kemudahan yang dapat menjelaskan penerimaan pengguna terhadap aplikasi efaktur versi 3.0. berikut :

Kerangka konseptual penelitian sebagai

Gambar 1

Kerangka Berpikir penelitian

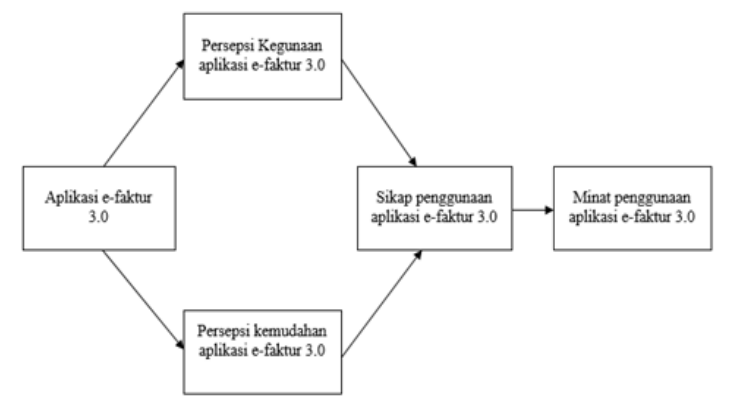

\section{METODE PENELITIAN}

Pendekatan kualitatif melalui wawancara mendalam dilakukan pada penelitian ini untuk menjawab pertanyaan penelitian. Informan penelitian ini adalah seluruh PKP yang merupakan pilot projecting aplikasi e-faktur versi 3.0 yang terdaftar di KPP Pratama Badung Utara sebanyak 5 PKP. Kutipan penting yang mewakili kode tertentu didokumentasikan dalam kode yang sesuai, sebagai data untuk dipaparkan pada bagian hasil. Agar prinsip anonimitas tetap terjaga, partisipan diberi kode I1 sampai I5. Hal ini dilakukan agar penyusunan laporan menjadi lebih efektif. Setiap kutipan informan dalam pemaparan hasil diberi kode partisipan.

\section{HASIL DAN PEMBAHASAN 4.1 HASIL}

Hasil analisis menunjukkan bahwa sebagian besar partisipan yang diwawancarai menyatakan bahwa aplikasi e-faktur versi 3.0 yang resmi diluncurkan pada tanggal 1 Oktober 2020 oleh DJP dapat diterima oleh PKP yang merupakan Pilot Projecting aplikasi efaktur versi 3.0 yang terdaftar di KPP Pratama Badung Utara. Penerimaan pengguna terhadap aplikasi e-faktur versi 3.0 sesuai dengan TAM yakni memenuhi unsur persepsi kegunaan dan persepsi kemudahan. Persepsi pengguna terhadap aplikasi e-faktur versi 3.0 dapat menjelaskan sikap terhadap penggunaan, yang pada akhirnya menentukan minat penggunaan.

a. Penerimaan aplikasi e-faktur versi 3.0 melalui persepsi kegunaan

Berdasarkan hasil analisis, koding yang mewakili persepsi kegunaan dari aplikasi e-faktur versi 3.0 ini dijelaskan dengan kode berikut:

1) Mempercepat pekerjaan

Berdasarkan hasil analisis kode mempercepat pekerjaan dengan penggunaan aplikasi e-faktur versi 3.0 dinyatakan oleh informan I1, "Ya, lebih lebih cepat lebih efisien juga."(I1). I2 menyatakan, "Kalau kemarin kan kita mau bongkar dulu, mereka juga kadang bilang sudah ngasih atau gimana, nah kalau sekarang kan kita tinggal bilang, 
oh ini belum gitu, ngebantu sih." (I2).

Pernyataan dari I3, "Karena tadi itu dia sebelumnya contoh kami ada anggaplah beberapa lembar faktur pajak masukan yang tadinya mungkin saya entry membutuhkan waktu ya kurang lebih sejam gitu ya bu, tapi dengan adanya prepopulated data, jadi lebih sangat cepat sekali enggak sampai 5 menit bu." (I3). Kata kunci lebih cepat yang disampaikan oleh informan, menunjukkan bahwa penggunaan aplikasi e-faktur 3.0 dapat mempercepat waktu yang dibutuhkan oleh pengguna untuk menyelesaikan pekerjaan. Pengguna akan menilai suatu teknologi berguna apabila berkurangnya waktu yang diperlukan untuk melakukan suatu pekerjaan dengan menggunakan sistem teknologi tersebut (Mlekus et al., 2020).

2) Meningkatkan Performa

Peningkatan kualitas pekerjaan dengan penggunaan suatu sistem teknologi sangat diharapkan oleh pengguna. Hal tersebut tercermin dengan meningkatnya performa pekerjaan diantaranya meminimalisir adanya kesalahan input. Sebagaimana dinyatakan I1, "Harapannya ya mempermudah dalam pelaporan PPN dan meng apa ya, menyedikitkan kekeliruan kekeliruan dalam pajak masukan. Kalau sekarang kan tambah efisien ya menurut saya." (I1).

I3 menyatakan, "walaupun fisik faktur pajaknya tuh belum ada di kantor gitu. Tapi saya jadi lebih yakin bahwa lawan transaksi itu nggak ada yang menunda pembayaran PPN nya lah." (I3). Pernyataan I5, "Ya jadi kalau dulu kan kita harus nunggu tuh dulu mbak apa namanya pajak apa faktur fisik nya kita harus nunggu dulu. Tapi kalau sekarang kan kita udah bisa langsung ini langsung load dari dari efaktur 3.0 ini." (I5).

Kata kunci meminimalisasi kekeliruan yang disampaikan oleh informan, menunjukkan bahwa penggunaan aplikasi e-faktur 3.0 dapat meningkatkan performa pekerjaan. Menurut pengguna sistem aplikasi efaktur versi 3.0 dapat mengurangi kesalahan dan kekeliruan dari pekerjaan yang dilakukan. Pekerjaan juga semakin meningkat kualitasnya dengan menggunakan aplikasi e-faktur versi 3.0. Sistem baru dikatakan berguna kalau dapat meningkatkan performa pekerjaan dan kualitas output (output quality) yang dilakukan oleh pengguna (Mlekus et al., 2020).

3) Meningkatkan Produktifitas

Penggunaan aplikasi e-faktur versi 3.0 dapat meningkatkan produktifitas pengguna. Hal ini tercermin diantaranya dengan menggunakan aplikasi e-faktur versi 3.0 dapat menghasilkan input data pajak masukan dalam jumlah yang lebih banyak dibandingkan apabila dilakukan input secara manual. Generate data pajak masukan by system pada aplikasi e-faktur versi 3.0 meningkatkan produktifitas.

Sebagaimana dinyatakan oleh partisipan berikut: "Karena saya lihat kan kerjaan kita juga dalam artian yang biasanya ngerekap dari awal ternyata sudah terbantu, terus dari pelaporannya juga langsung otomatis." (I2). Pernyataan dari I3, "Tadinya closing PPN-nya saya itu bisa anggaplah, di tanggal 20 ke atas bu, karena kenapa, karena kan menunggu fisik faktur pajak dari vendor tapi dengan ada prepopulated data ini, saya sudah punya data rekapan." (I3).

Kata kunci tidak perlu membuat rekapan yang disampaikan oleh informan, menunjukkan bahwa penggunaan aplikasi e-faktur 3.0 dapat meningkatkan produktifitas. Data Pajak Masukan yang sudah tersedia melalui sistem (prepopulated) pada aplikasi efaktur 3.0, menjadikan pengguna tidak lagi input data secara manual seperti 
pada aplikasi e-faktur sebelumnya.

Pengguna juga bisa langsung mengetahui data pajak masukan yang dimiliki walaupun fisik faktur pajak belum diterima dari lawan transaksi. Hal ini merupakan temuan yang sangat penting. Aplikasi e-faktur versi 3.0 dapat dengan mudah diterima oleh pengguna dengan adanya menu prepopulated pajak masukan. Suatu teknologi informasi dapat dengan mudah diterima oleh pengguna apabila memenuhi persepsi peningkatan produktivitas (productivity performance expectancy) (Bhuasiri et al., 2016).

4) Efektifitas

Aplikasi e-faktur versi 3.0 mampu meningkatkan efektifitas dalam melakukan suatu pekerjaan. Input data pajak masukan yang sebelumnya memakan waktu berjam-jam dapat dipangkas dengan menggunakan aplikasi e-faktur versi 3.0. Sebagaimana dijelaskan oleh I1, "Ya, lebih efektif." (I1). Pernyataan I2, "Lebih efektif, ya karena kan langsung dia dari e-faktur online nya itu ya." (I2).

Kata kunci efektif yang disampaikan oleh informan, menunjukkan bahwa penggunaan aplikasi e-faktur 3.0 dapat meningkatkan efektifitas. Menurut pengguna aplikasi e-faktur versi 3.0 sangat efektif digunakan dalam penyelesaian pekerjaan. Terutama dengan adanya menu prepopulated pajak masukan pada aplikasi e-faktur versi 3.0. Pengguna akan menggunakan teknologi informasi khususnya dalam bidang pemerintahan yang semakin meningkatkan efektivitas penggunanya (Bhuasiri et al., 2016).

5) Mempermudah Pekerjaan

Pengguna aplikasi e-faktur versi 3.0 akan menilai aplikasi ini berguna apabila membantu pengguna dalam melakukan pekerjaan yang awalnya sulit menjadi lebih mudah dikerjakan. Berikut pernyataan partisipan terkait aplikasi e-faktur versi 3.0 yang dapat mempermudah pekerjaan, "yang pertama yang di make in di propulate datanya itu, itu sangat memudahkan terus pada saat impor PIB itu juga mudah sih menurut saya." (I1). I3 menyatakan, "Prepopulated data dan laporan menggunakan web based itu sangat simpel sekali, kita nggak tanpa masukkan CSV gitu ya, datanya sudah langsung terkoneksi gitu, terus laporannya juga hanya klik satu kali menu bu, lapor itu mudah banget bu." (I3).

Kata kunci memudahkan yang disampaikan oleh informan, menunjukkan bahwa penggunaan aplikasi e-faktur 3.0 dapat mempermudah pekerjaan. Pekerjaan yang awalnya dilakukan input secara manual, sekarang sudah tersistem. Prepopulated data yang tersedia pada aplikasi e-faktur 3.0 tidak hanya data pajak masukan, tapi juga data PIB. Mempermudah pekerjaan merupakan salah satu persepsi kegunaan yang diinginkan pengguna pada sistem teknologi (Rodrigues Pinho \& Soares, 2011).

6) Bermanfaat dan membantu

Manfaat implementasi suatu teknologi akan sangat dirasakan oleh pengguna apabila sistem teknologi tersebut berguna dalam penyelesaian pekerjaan. Pengguna akan menganggap aplikasi efaktur versi 3.0 ini berguna apabila aplikasi e-faktur versi 3.0 membantu penyelesaian pekerjaan. Hal ini dijelaskan dari pernyataan I2, "cuman kan kelebihannya ada tambahan PPN Masukan nya tidak perlu kita ngerekap lagi ya. Jadi kita sudah bisa cek secara datanya sudah ada tinggal kita tandingin dengan fisiknya, ini sih lebih membantu sih bu. Selanjutnya I3 menambahkan, "Apalagi dengan menu terbarunya, prepopulated data itu. Itu sangat membantu sekali bu." (I3).

Kata kunci membantu yang
disampaikan oleh informan,


menunjukkan bahwa penggunaan aplikasi e-faktur 3.0 bermanfaat dan membantu. Pengguna merasa sangat terbantu dengan adanya sistem aplikasi e-faktur versi 3.0 ini. Dengan adanya data pajak masukan yang langsung di load pada aplikasi e-faktur versi 3.0, pengguna bahkan tidak perlu menunggu faktur pajak fisik untuk melakukan pengkreditan pajak masukan pada laporan SPT Masa PPN tiap bulan yang dilaporkan ke Kantor Pelayanan Pajak. Pengguna cukup mengakses menu data pajak masukan dan untuk melakukan pengkreditan pajak masukan dapat dipilih sesuai dengan masa pajak atau maksimal 3 bulan setelah berakhirnya masa pajak. Penggunaan suatu sistem informasi yang bermanfaat akan menjadikan pengguna menjadi semakin berminat menggunakan sistem tersebut (favourable toward the system) (Taherdoost, 2018).

7) Monitoring Data

Dengan penggunaan aplikasi e-faktur versi 3.0, monitoring data baik data pajak masukan maupun data pajak keluaran lebih sistematis dan valid. Sebagaimana dinyatakan I1, "Mungkin ada tambahannya dari beberapa supplier kita yang faktur pajaknya secara fisik kita tidak terima namun dengan aplikasi faktur yang terbaru kita bisa mendeteksi gitu." (I1). Pernyatan I1 juga diperkuat dengan pernyataan I2, "Karena kan semua data sudah ada, biasanya kan kadang kita lewat, bisa masuk B3, kalau sekarang kan tanpa kita lihat, sudah muncul semua kan fakturnya." (I2).

Pernyataan dari I4, "di mana kemarinkemarin mungkin faktur masukan itu bisa jadi salah satu celah untuk kita pengguna faktur, dimana lawan transaksi kita kan kadang tidak masukkan faktur faktur pajak keluaran yang kita keluarkan ke pihak klien kadang mereka enggak masukin ke faktur masukan kan mbak ya, tapi kan dengan adanya tambahan aplikasi ini mungkin lebih mengontrol gitu lho mbak terkait faktur pajak masukan nya." (I4). I5 juga menambahkan, "ya lebih gampang diawasin berarti ya mbak ya, lebih mudah mengawasi berarti." (I5).

Kata kunci kontrol yang disampaikan oleh informan, menunjukkan bahwa penggunaan aplikasi e-faktur 3.0 dapat memonitoring data. Sebagian besar pengguna sistem aplikasi e-faktur versi 3.0 merasa bahwa penggunaan sistem aplikasi e-faktur versi 3.0 dapat memonitoring data baik data pajak masukan maupun data pajak keluaran secara lebih sistematis dan real time. Monitoring data dapat dilakukan per bulan sesuai dengan masa pajak pelaporan SPT Masa PPN atau dilakukan selama satu tahun pajak. Data yang lebih sistematis akan memudahkan pengguna untuk mengukur kinerja perusahaan. Pengguna akan memilih menggunakan suatu sistem informasi yang mampu mengontrol dan memonitor kegiatan yang dilakukan (Beldad \& Hegner, 2018).

b. Penerimaan aplikasi e-faktur versi 3.0 melalui persepsi kemudahan

Berdasarkan hasil analisis, koding yang mewakili persepsi kemudahan dari penerapan sistem aplikasi e-faktur versi 3.0 ini berkaitan dengan hal-hal berikut:

1) Mudah dipelajari

Pengguna akan memilih menggunakan suatu sistem teknologi yang mudah dipelajari dan tidak rumit. Fitur aplikasi e-faktur 3.0 seharusnya ditampilkan sederhana sehingga dapat dengan mudah dipelajari oleh pengguna yang baru. Berikut pernyataan I1 terkait hal ini, " $Y a$ user friendly." (I1).

Hal senada juga disampaikan oleh I2, "Nggak terlalu sulit untuk orang awam yang baru buka pun mungkin nggak terlalu lama untuk belajar nya." (I2). I3 
menyatakan, "Yang ada tambahan prepopulated data dan prepopulated datanya pun sangat mudah gitu, hanya tinggal masukkan bulan tahun get data gitu, itu sangat sederhana sih bu." (I3). Kemudian I4 menyampaikan, "Sejauh ini sih enggak ada kendala sih mbak untuk tampilan menunya di situ." (I4).

Kata kunci tampilan sederhana yang disampaikan oleh informan, menunjukkan bahwa aplikasi e-faktur 3.0 dapat meningkatkan mudah dipelajari. Menurut informan, sistem aplikasi efaktur versi 3.0 ini sangat mudah dipelajari dan user friendly. Tampilan menu yang ada pada sistem aplikasi efaktur versi 3.0 mudah digunakan oleh user saat mengoperasikan aplikasi efaktur versi 3.0. Pengguna tidak sampai mengalami kebingungan saat mengakses menu yang ada pada pada sistem aplikasi e-faktur versi 3.0. Sistem informasi yang mudah digunakan (easy to use) lebih menarik minat penggunaan (Ratna \& Mehra, 2015).

2) Dapat dikontrol

Pengguna akan menilai bahwa aplikasi e-faktur 3.0 memudahkan untuk melakukan kontrol terhadap pekerjaan yang dilakukan apabila pada sistem dapat menampilkan apa yang dibutuhkan oleh pengguna. Misalnya pengguna ingin mengetahui jumlah pajak masukan yang dapat dikreditkan pada suatu bulan tertentu, maka aplikasi efaktur 3.0 harus dapat menampilkan data tersebut dengan cepat. Sebagaimana dinyatakan oleh I2, "Dalam artian kita sebagai wajib pajak dan DJP kita samasama tahu, datanya juga sama-sama lebih rapih ya kan." (I2).

Pernyataan dari I3, "Kami pun sebagai wajib pajak lebih merasa nyaman ya bu ya. Maksudnya DJP menyediakan aplikasi yang sudah saling terkoneksi antara Bea Cukai dengan kantor pajak, terus kemudian antara kami dengan lawan transaksi begitu." (I3). Hal yang senada juga dinyatakan oleh I4, "dimana kita dalam pelaporan ini kan dia sudah langsung conect gitu kita nggak perlu lagi kayak iniin ke e-filling nya." (I4). Kemudian I5 menyampaikan, "Ya, lebih lebih terkontrol jadi mbak, lebih lebih terkontrol." (I5).

Kata kunci data rapih dan terkontrol yang disampaikan oleh informan, menunjukkan bahwa aplikasi e-faktur 3.0 dapat memudahkan pengguna untuk mengontrol pekerjaan. Administrasi data yang rapi membuat pengguna mudah dalam melakukan pengawasan. Pengguna menilai bahwa aplikasi efaktur versi 3.0 menjadikan kontrol terhadap data pajak masukan lebih sistematis. Suatu sistem yang mudah digunakan dan dikontrol akan meningkatkan keinginan (willingness) pengguna untuk menggunakan sistem tersebut (Liao et al., 2018).

3) Jelas dan dapat dipahami

Menu yang terdapat pada aplikasi efaktur 3.0 harus jelas dan mudah dipahami oleh pengguna. Beberapa pernyataan yang menyatakan hal ini yaitu, "Sama aja sih. Jadi kalau misalnya kita sudah menggunakan versi sebelumnya untuk menggunakan versi terbaru ini sama saja menurut saya, lebih sama-sama mudah dipahami." (I1). "Sangat sangat bu, bisa lah bu kalau yang baru belum pernah buka, satu atau dua hari pasti bisa." (I2). Pernyataan I3 menyatakan, "Mudah bu dipahami, dari mulai tampilannya sekarang lebih bagus ya, logo DJP nya sudah baru terus kemudian menu-menunya fiturnya juga tidak merubah banyak ya itu ibu." (I3).

Kata kunci mudah dipahami yang disampaikan oleh informan, menunjukkan bahwa aplikasi e-faktur 3.0 memudahkan pengguna dalam memahami cara penggunaanya. Pengguna merasa interface dan tampilan dari sistem aplikasi e-faktur versi 3.0 ini sangat jelas sehingga memudahkan pengguna untuk memahaminya. Tampilan fitur yang sederhana dan 
mudah dipahami akan memudahkan bagi pengguna untuk menggunakan aplikasi e-faktur 3.0, bahkan oleh pengguna yang baru pertama menggunakan aplikasi e faktur 3.0. Kejelasan dan kemudahan sistem informasi akan meningkatkan positive attitude user dalam penggunaan suatu sistem teknologi (Yasa et al., 2014).

4) Fleksibel

Penggunaann sistem aplikasi e-faktur versi 3.0 yang merupakan web based dapat meningkatkan fleksibilitas penggunanya. Pengguna dapat mengakses aplikasi efaktur versi 3.0 dari mana saja dan kapan pun diperlukan. Tidak lagi harus melakukan instal seperti versi sebelumnya yang berbasis client desktop.

Sebagaimana dinyatakan oleh I4, "Kalau menurut saya, ya sih mbak lebih fleksibel dibandingkan e-faktur yang sebelumnya karena kan ada tambahan-tambahan menu yang lebih mempermudah kita gitu lho mbak untuk melakukan input faktur masukan maupun dalam pelaporan SPT nya sendiri mbak." (I4). I5 juga menambahkan, "Ya, lebih fleksibel yang sekarang mbak."(I5). "Kalau dulu kan kita nggak nggak bisa maksudnya nggak bisa pindah-pindahin apa namanya agak susah gitu loh mau mindah mindahin itu agak susah gitu, kalau sekarang pakai web based ya lebih lebih fleksibel lah dia mbak." (I5).

Kata kunci lebih fleksibel yang disampaikan oleh informan, menunjukkan bahwa aplikasi e-faktur versi 3.0 dapat diterima pengguna yang membutuhkan fleksibilitas dalam penyelesaian pekerjaan. Dengan berbasis web (web based), aplikasi e-faktur versi 3.0 dirasakan pengguna sangat fleksibel, karena pengguna tidak perlu lagi melakukan install pada komputer/laptop seperti pada aplikasi e-faktur versi sebelumnya yang masih berbasis client desktop. Pengguna hanya tinggal mengakses alamat website dari e-faktur di laman https://efaktur.pajak.go.id/.
Fleksibilitas ini juga merupakan temuan yang penting dalam penerimaan pengguna terhadap aplikasi e-faktur versi 3.0.

5) Mudah mahir

Suatu sistem teknologi baru diharapkan tidak membutuhkan waktu yang lama bagi pengguna untuk mempelajarinya. Fitur-fitur yang terdapat dalam aplikasi e-faktur versi 3.0 harus dapat dipahami oleh pengguna dalam waktu yang singkat. Pengguna tidak merasa membuang-buang waktu hanya untuk mempelajari aplikasi baru tersebut.

Sebagaimana tergambar dalam beberapa pernyataan berikut, "1 hari sih sudah bisa ya." (I1). "saya aja dalam artian ya, nggak ngak, jarang berkecimpung dengan lihat e-faktur, kalau ngelihat satu atau dua hari bisa lah bu." (I2). "Lebih cepat, satu hari aja bisa bu. Karena ngak ada yang terlalu susah kan ya." (I2). Hal senada juga dinyatakan oleh I3, "Mungkin kurang kurang dari 1 jam ya bu ya, karena bagus banget sederhana sekali gitu, terus DJP juga sudah menyediakan informasi nya bagus sekali gitu bu." (I3).

Kata kunci satu hari dan satu jam yang disampaikan oleh informan, menunjukkan bahwa pengguna aplikasi e-faktur 3.0 dapat memahami aplikasi dalam waktu yang singkat. Pengguna tidak memerlukan waktu yang lama untuk memahami aplikasi e-faktur versi 3.0. Pengguna yang jarang berkecimpung dan mengakses aplikasi e-faktur juga dapat memahami aplikasi e-faktur versi 3.0 dalam waktu yang tidak terlalu lama. pengguna lebih berminat menggunakan sistem yang memudahkan pengguna untuk mahir menggunakan sistem tersebut (easy to become skillfull) (Koul \& Eydgahi, 2018).

6) Mudah digunakan

Pengguna aplikasi e-faktur versi 3.0 akan menilai bahwa aplikasi ini mudah digunakan apabila tidak diperlukan waktu yang lama untuk mengakses 
aplikasi ini. Koneksi jaringan yang stabil juga sangat berperan dalam meningkatkan kemudahan penggunaan aplikasi. Sebagaimana dijelaskan oleh I1, "Cukup mudah dipahami." (I1).

Hal senada juga disampaikan oleh I3, "Bagus bu. Saya merasakan kemudahan dengan lapor menggunakan web based ya. (I3). "Ya, lebih simple dan koneksinya lebih bagus." (I3). I4 menjelaskan, "Menurut saya mudah ya mbak ya, hampir sama dengan aplikasi yang sebelumnya, cuma ada penambahan satu item lagi disitu ya mbak ya." (I4). Kemudian I5 juga menambahkan, "Mudah sih mbak, karena mungkin karena saya sudah terbiasa ya maksudnya udah sering pakai e-faktur ya saya sih, kalau saya sendiri sih mudah ngelihatnya gitu loh." (I5).

Kata kunci mudah digunakan yang disampaikan oleh informan, menunjukkan bahwa aplikasi e-faktur 3.0 dapat diterima oleh pengguna. Pengguna menilai bahwa aplikasi e-faktur versi 3.0 mudah digunakan. Koneksi jaringan aplikasi e-faktur juga lebih stabil sehingga pengguna lebih mudah dalam mengakses. Sistem teknologi yang dirasakan mudah digunakan oleh penggunanya, membuat pengguna merasa responsif dan akan berpengaruh pada ketertarikan untuk menggunakannya (Bahari et al., 2020).

7) Kendala cepat teratasi

Persepsi pengguna aplikasi e-faktur versi 3.0 akan merasa penggunaan aplikasi e-faktur versi 3.0 mudah apabila kendala yang dialami saat menggunakan aplikasi e-faktur versi 3.0 cepat teratasi. Sebagaimana dinyatakan oleh I1, "Cukup cepat tanggap sih." (I1). "Biasanya sih kalau sudah siang error itu sampai beberapa jam, hanya berlaku beberapa jam sih." (I1). Hal senada juga dinyatakan oleh I2, "tapi kalau sepanjang itu sih kalau masalah koneksi satu atau dua jam sih uda jalan lagi sih." (I2).

Kata kunci beberapa jam yang disampaikan oleh informan, menunjukkan bahwa aplikasi e-faktur versi 3.0 dapat diterima oleh pengguna karena kendala cepat teratasi. Pengguna tidak harus menunggu lama apabila terjadi kendala dalam penggunaan aplikasi e-faktur versi 3.0. Biasanya error aplikasi dapat teratasi hanya dalam beberapa jam saja. Sejumlah variabel eksternal seperti pengetahuan, keterampilan user, dan pengalaman, juga akan berkontribusi pada persepsi pengguna tentang kemudahan suatu sistem teknologi (Siegel et al., 2017). Kendala yang dialami pengguna aplikasi e-faktur versi 3.0 juga berhubungan dengan variabel eskternal yang ditemukan oleh Siegel.

8) Intensitas pemakaian

Suatu sistem aplikasi e-faktur versi 3.0 yang intens digunakan berkala menunjukkan bahwa aplikasi tersebut mudah dan gampang diakses oleh pengguna. Pemakaian aplikasi e-faktur versi 3.0 yang intensif menjadikan aplikasi ini dapat diterima oleh pengguna. Beberapa pernyataan yang menjelaskan hal ini, "Setiap hari ya. Tiap hari selama hari kerja." (I1). "dua mingguan biasanya." (I2).

Kata kunci mingguan dan harian yang disampaikan oleh informan, menunjukkan bahwa aplikasi e-faktur versi 3.0 secara intens digunakan oleh pengguna. Penggunaan yang intens menggambarkan bahwa aplikasi e-faktur versi 3.0 dapat diterima oleh pengguna. Bahkan terdapat informan yang menggunakan aplikasi e-faktur versi 3.0 setiap hari dalam pekerjaannya. Perasaan positif pengguna terkait kemudahan menggunakan teknologi berkaitan dengan penggunaan teknologi oleh user secara berkelanjutan (sustained using technology) (Amer et al., 2013).

c. Persepsi kegunaan dan persepsi kemudahan dapat menjelaskan sikap terhadap penggunaan aplikasi e-faktur versi 3.0

Sikap terhadap penggunaan sistem 
aplikasi e-faktur versi 3.0, keseluruhan menilai bahwa sistem aplikasi e-faktur versi 3.0 sangat membantu dan membuat pengguna bersikap ingin menggunakan aplikasi e-faktur versi 3.0. Sebagaimana dinyatakan oleh I1, "untuk saat ini sih sudah sesuai ya." (I1).

Pernyataan I2, "Yang ini sih saya lihat, mendukung dia." (I2). Hal senada juga disampaikan oleh I3, "Fiturnya semua sih sudah bagus ya bu ya." (I3). Pernyataan I5, "Oh iya mbak, apa namanya sudah sesuai dengan yang diinginkan." (I5).

Kata kunci sudah sesuai yang disampaikan oleh informan, menunjukkan bahwa persepsi kegunaan dan persepsi kemudahan pengguna dapat menjelaskan sikap terhadap penggunaan aplikasi efaktur 3.0. Informan menjelaskan bahwa aplikasi e-faktur versi 3.0 sudah sesuai keinginan dari pengguna. Pengguna juga menilai bahwa aplikasi e-faktur versi 3.0 ini sangat mendukung dalam pekerjaan.

d. Sikap terhadap penggunaan aplikasi efaktur versi 3.0 dapat menjelaskan minat penggunaan aplikasi e-faktur versi 3.0

Minat penggunaan sistem aplikasi efaktur versi 3.0 secara jelas tergambar dalam beberapa pernyataan informan sebagai berikut: "Ya berminat, karena sangat membantu." (I1). Pernyataan I2, "Oo pasti akan dipakai bu, pasti akan dipakai, pasti lebih pakai ini lah bu." (I2). Pernyataan I3 menyatakan, "Betul, dari yang selama ini digunakan dari 3.0 ini yang paling bagus bu, yang paling cepat yang paling sangat membantu." (I3).

Kata kunci berminat yang disampaikan oleh informan, menunjukkan bahwa informan berminat menggunakan aplikasi efaktur versi 3.0. Sikap terhadap penggunaan aplikasi e-faktur versi 3.0 dapat menjelaskan minat penggunaan aplikasi e-faktur versi 3.0. Sikap pengguna yang menilai bahwa aplikasi e-faktur versi 3.0 yang sudah sesuai kebutuhan dan sangat membantu menjadikan pengguna sangat berminat menggunakan aplikasi e-faktur versi 3.0 ini.

Berikut disajikan tabel dan gambar mengenai ringkasan tema dan kode hasil analisis transkrip wawancara aplikasi efaktur versi 3.0.

Tabel 1

Ringkasan Tema dan Kode Hasil Analisis

\begin{tabular}{|l|c|}
\hline \multicolumn{1}{|c|}{ Tema dan Kode } & Jumlah Respon \\
\hline Tema 1 : Persepsi kegunaan & \\
Kode 1.1 : Mempercepat pekerjaan & 5 \\
Kode 1.2 : Meningkatkan performa & 3 \\
Kode 1.3 : Meningkatkan produktifitas & 4 \\
Kode 1.4 : Efektifitas & 5 \\
Kode 1.5 : Mempermudah pekerjaan & 5 \\
Kode 1.6 : Bermanfaat dan membantu & 5 \\
Kode 1.7 : Monitoring data & \\
Tema 2: Persepsi kemudahan & \\
Kode 2.1 : Mudah dipelajari & 4 \\
Kode 2.2: Dapat dikontrol & 4 \\
Kode 2.3 : Jelas dan dapat dipahami & 4 \\
Kode 2.4 : Fleksibel & 5 \\
Kode 2.5: Mudah mahir & 3 \\
Kode 2.6 : Mudah digunakan & 5 \\
Kode 2.7 : Kendala cepat teratasi & 5 \\
Kode 2.8: Intensitas pemakaian & 5 \\
Tema 3 : Sikap terhadap penggunaan & 5 \\
Tema 4 : Minat penggunaan & \\
& \\
\hline
\end{tabular}

Gambar 2

Model Hubungan Antar Tema

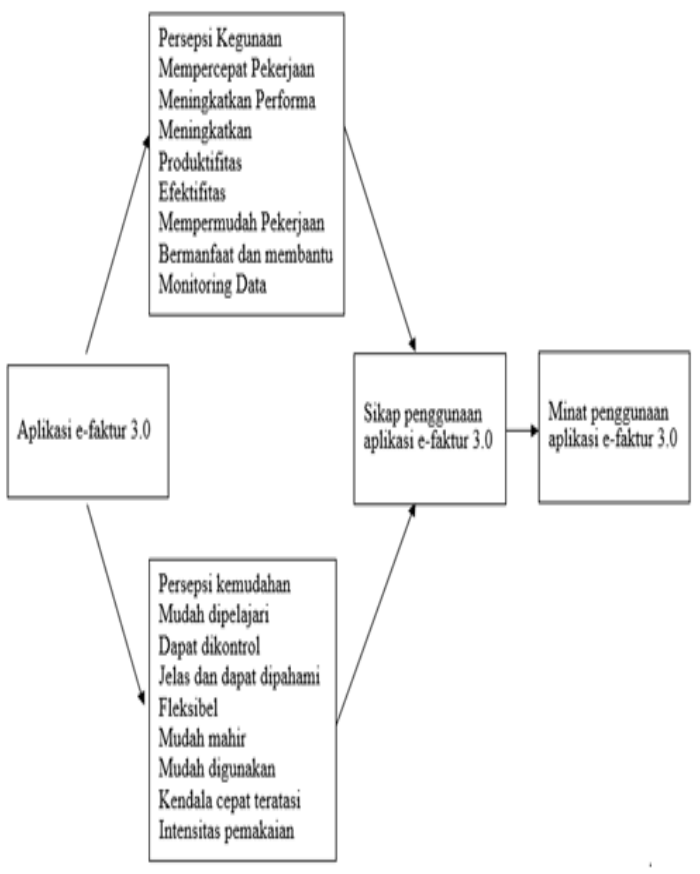

\subsection{Pembahasan}

Berdasarkan hasil analisis dan pengolahan 
data ditemukan bahwa TAM dapat menjelaskan bagaimana penerimaan pengguna terhadap aplikasi e-faktur versi 3.0. Peran mediasi dari dua variabel yakni persepsi kegunaan dan persepsi kemudahan merupakan faktor utama yang dapat menjelaskan bagaimana penerimaan pengguna terhadap aplikasi e-faktur versi 3.0.

Persepsi kegunaan aplikasi e-faktur versi 3.0 yang ditemukan dalam penelitian ini meliputi mempercepat pekerjaan, meningkatkan performa, meningkatkan produktifitas, efektifitas, mempermudah pekerjaan, bermanfaat dan membantu serta monitoring data. Dari sisi mempercepat pekerjaan, pengguna akan menilai suatu teknologi berguna apabila berkurangnya waktu yang diperlukan untuk melakukan suatu pekerjaan dengan menggunakan sistem teknologi tersebut (Mlekus et al., 2020). Sebagian besar informan menyatakan bahwa aplikasi e-faktur versi 3.0 berguna untuk mempercepat pekerjaan. Pekerjaan yang dilakukan sebelum adanya aplikasi e-faktur versi 3.0 harus dilakukan input satu per satu secara manual, namun sejak adanya aplikasi efaktur versi 3.0 tidak perlu lagi dilakukan.

Sistem baru dikatakan berguna dapat meningkatkan performa pekerjaan dan kualitas output (output quality) yang dilakukan oleh pengguna (Mlekus et al., 2020). Berkaitan dengan hasil wawancara, sebagian besar informan menjelaskan bahwa aplikasi e-faktur versi 3.0 meningkatkan performa pekerjaan. Informan menyampaikan bahwa kekeliruan dan kesalahan penginputan data yang sering dilakukan pada aplikasi e-faktur sebelumnya dapat diminimalisir dengan penggunaan aplikasi e-faktur versi 3.0 ini. Selain itu cross check data dapat langsung dilakukan tanpa menunggu adanya faktur pajak fisik yang dikirim oleh lawan transaksi.

Pemanfaatan sistem aplikasi e-faktur versi 3.0 telah meningkatkan produktifitas pekerjaan dari pengguna aplikasi e-faktur versi 3.0. Hal ini telah ditunjukkan dalam wawancara bahwa aplikasi e-faktur versi 3.0 sangat meningkatkan produktifitas pekerjaan yang dilakukan. Pekerjaan yang dulu hanya bisa dikerjakan setelah menerima fisik dari faktur pajak dari vendor dan lawan transaksi, sekarang sudah bisa dilakukan hanya dengan mengakses data pajak masukan di aplikasi e-faktur versi 3.0.

Temuan penelitian ini menemukan bahwa sebagian besar pengguna menilai aplikasi efaktur versi 3.0 telah meningkatkan produktifitas pekerjaan sehingga aplikasi efaktur versi 3.0 dapat diterima oleh pengguna. Temuan ini sesuai dengan hasil penelitian Bhuasiri (2016), bahwa suatu teknologi informasi dapat dengan mudah diterima oleh pengguna apabila memenuhi persepsi peningkatan produktivitas (productivity performance expectancy) (Bhuasiri et al., 2016).

Pengguna akan menggunakan teknologi informasi khususnya dalam bidang pemerintahan yang semakin meningkatkan efektivitas penggunanya (Bhuasiri et al., 2016). Berdasarkan hasil wawancara yang dilakukan, peneliti menemukan bahwa aplikasi e-faktur versi 3.0 lebih efektif dibandingkan aplikasi sebelumnya. Pengguna menilai bahwa aplikasi e-faktur versi 3.0 yang saat ini sudah memiliki menu prepopulated pajak masukan sangat efektif bagi pengguna yang ingin mengkreditan pajak masukan pada pelaporan SPT Masa PPN.

Mempermudah pekerjaan merupakan salah satu persepsi kegunaan yang diinginkan pengguna pada sistem teknologi (Rodrigues Pinho \& Soares, 2011). Aplikasi e-faktur versi 3.0 memudahkan pengguna dalam melakukan pekerjaanya. Berdasarkan wawancara, sebagian besar informan menjelaskan bahwa aplikasi e-faktur versi 3.0 sangat mempermudah pekerjaan.

Penggunaan suatu sistem informasi yang bermanfaat akan menjadikan pengguna menjadi semakin berminat menggunakan sistem tersebut (favourable toward the system) (Taherdoost, 2018). Pengguna aplikasi e-faktur versi 3.0 menilai bahwa sistem aplikasi e-faktur versi 3.0 sangat berguna. Sejak adanya sistem aplikasi e-faktur versi 3.0 ini, banyak pekerjaan rumit menjadi lebih mudah dilakukan.

Temuan penelitian yang dilakukan oleh Beldad \& Hegner (2018) menunjukkan bahwa pengguna akan memilih menggunakan suatu sistem informasi yang mampu mengontrol dan 
memonitor kegiatan yang dilakukan (Beldad \& Hegner, 2018). Monitoring data yang lebih baik merupakan salah satu penilaian pengguna terhadap aplikasi e-faktur versi 3.0. Hal ini telah ditunjukkan dalam wawancara bahwa pengguna menilai bahwa monitoring data pajak masukan dapat dilakukan secara langsung hanya dengan mengakses aplikasi efaktur versi 3.0.

Persepsi kemudahan aplikasi e-faktur versi 3.0 yang dijelaskan dalam penelitian ini meliputi mudah dipelajari, dapat dikontrol, jelas dan dapat dipahami, fleksibel, mudah mahir, mudah digunakan, kendala cepat teratasi, serta intensitas pemakaian. Temuan penelitian Ratna \& Mehra (2015) menunjukkan bahwa sistem informasi yang mudah digunakan (easy to use) lebih menarik minat penggunaan (Ratna \& Mehra, 2015). Anggapan kemudahan pemakaian e-faktur versi 3.0 salah satunya ditentukan dengan kemudahan untuk mempelajarinya. Pengguna akan memilih menggunakan suatu sistem teknologi yang mudah dipelajari dan tidak rumit.

Suatu sistem yang mudah digunakan dan dikontrol akan meningkatkan keinginan (willingness) pengguna untuk menggunakan sistem tersebut (Liao et al., 2018). Berdasarkan hasil analisis wawancara menunjukkan informan menilai kontrol terhadap faktur pajak dapat dengan mudah dilakukan menggunakan sistem aplikasi e-faktur versi 3.0. Informan juga menyatakan bahwa aplikasi efaktur versi 3.0 yang sudah terkoneksi dengan data pada DJP sangat diapresiasi oleh pengguna.

Kejelasan dan kemudahan sistem informasi akan meningkatkan positive attitude user dalam penggunaan suatu sistem teknologi (Yasa et al., 2014). Kejelasan ini didukung dengan tampilan aplikasi yang eye catching dan tidak membingungkan pengguna dalam menggunakan sistem aplikasi e-faktur versi 3.0. Sebagian besar pengguna menilai bahwa tampilan menu pada aplikasi e-faktur versi 3.0 jelas dan mudah dipahami.

Berdasarkan hasil wawancara, sebagian besar pengguna menilai bahwa aplikasi efaktur versi 3.0 sangat fleksibel. Saat ini sistem aplikasi e-faktur versi 3.0 sudah berbasis web (web based) sehingga memungkinkan pengguna aplikasi e-faktur versi 3.0 dapat menggunakan aplikasi tanpa proses instalasi terlebih dahulu di komputer/laptop. Akses aplikasi e-faktur versi 3.0 dapat dilakukan dari perangkat komputer yang berbeda.

Temuan penelitian yang dilakukan oleh Koul \& Eydgahi (2018) menunjukkan bahwa pengguna lebih berminat menggunakan sistem yang memudahkan pengguna untuk mahir menggunakan sistem tersebut (easy to become skillfull) (Koul \& Eydgahi, 2018). Hasil analisis transkrip wawancara menunjukkan bahwa pengguna aplikasi e-faktur versi 3.0 sudah bisa menggunakan suatu sistem aplikasi e-faktur versi 3.0 dalam waktu yang cepat. Bahkan ada informan yang menyatakan bahwa sudah dapat memahami aplikasi e-faktur versi 3.0 dalam waktu kurang dari 1 jam.

Penelitian Bahari (2020) menemukan bahwa sistem teknologi yang dirasakan mudah digunakan oleh penggunanya, membuat pengguna merasa responsif dan akan berpengaruh pada ketertarikan untuk menggunakannya (Bahari et al., 2020). Sebagian besar pengguna sistem aplikasi e-faktur versi 3.0 menyatakan bahwa sistem aplikasi e-faktur versi 3.0 mudah digunakan. Terlebih dengan adanya tambahan menu prepopulated data pajak masukan dan PIB, dinilai pengguna sangat mudah untuk digunakan.

Kendala yang dialami oleh user dalam penggunaan suatu aplikasi akan dapat menjelaskan persepsi kemudahan suatu sistem informasi. Temuan ini mendukung temuan penelitian yang dilakukan oleh Siegel (2017) dimana sejumlah variabel eksternal seperti pengetahuan, keterampilan user, dan pengalaman, juga akan berkontribusi pada persepsi pengguna tentang kemudahan suatu sistem teknologi (Siegel et al., 2017). Kendala yang dialami pengguna aplikasi e-faktur versi 3.0 juga berhubungan dengan variabel eskternal yang ditemukan oleh Siegel.

Hasil penelitian Amer (2013), bahwa perasaan positif pengguna terkait kemudahan menggunakan teknologi berkaitan dengan penggunaan teknologi oleh user secara 
berkelanjutan (sustained using technology) (Amer et al., 2013). Berdasarkan hasil analisis, sebagian besar pengguna dari aplikasi e-faktur versi 3.0 secara rutin menggunakan aplikasi efaktur versi 3.0 setiap bulannya. Pengguna memanfaatkan aplikasi e-faktur versi 3.0 tidak hanya untuk pengkreditan pajak masukan saja, namun juga untuk melaporkan SPT Masa PPN. Periode pengguna mengakses aplikasi e-faktur versi 3.0 mulai dari satu kali dalam sebulan sampai tiap hari kerja dalam sebulan. Hal ini menunjukkan bahwa intensitas pemakaian aplikasi e-faktur versi 3.0 cukup tinggi.

Persepsi kegunaan dan persepsi kemudahan dapat menjelaskan sikap terhadap penggunaan aplikasi e-faktur versi 3.0. Menurut penelitian Bundot et al (2017) menunjukkan bahwa sikap pengguna terhadap teknologi mengacu pada bagaimana pengguna mengevaluasi positif atau negatif terhadap suatu teknologi baru (Bundot et al., 2017). Dari hasil analisis transkrip wawancara yang dilakukan, peneliti melihat sebagian besar pengguna menunjukkan sikap yang positif dan tertarik menggunakan aplikasi e-faktur versi 3.0 karena dinilai sangat memudahkan dan membantu dalam pekerjaan yang dilakukan. Beberapa informan menyatakan bahwa aplikasi e-faktur versi 3.0 sangat mendukung dan memenuhi keinginan dari pengguna aplikasi efaktur versi 3.0. Pengguna menilai penggunaan aplikasi e-faktur versi 3.0 sudah sesuai untuk mendukung pekerjaan yang dilakukan selama ini.

Sikap terhadap penggunaan dapat menjelaskan minat penggunaan aplikasi efaktur versi 3.0. Temuan penelitian yang dilakukan oleh Phua (2012) menemukan bahwa minat penggunaan suatu teknologi (intention to use technology) yang tinggi akan mencerminkan penerimaan dan penggunaan teknologi oleh user dan hal ini merupakan ukuran kunci keberhasilan suatu sistem teknologi (Phua et al., 2012). Sebagian besar pengguna menyatakan berminat untuk menggunakan aplikasi e-faktur versi 3.0. Pengguna menilai menu tambahan yang terdapat dalam aplikasi e-faktur versi 3.0 membuat pengguna merasa sangat terbantu dalam menyelesaikan pekerjaan yang dulunya memerlukan waktu yang lama, namun sejak menggunakan aplikasi e-faktur versi 3.0 menjadi sangat cepat.

Sekalipun penelitian dilaksanakan pada PKP terdaftar di KPP Pratama Badung Utara, Bali, temuan penelitian ini relevan pula pada konteks KPP di seluruh Indonesia. Hal ini disebabkan karena implementasi aplikasi efaktur versi 3.0 diterapkan di seluruh Indonesia. Persepsi pengguna dalam menggunakan aplikasi e-faktur versi 3.0 menjelaskan sikap pengguna dan minat penggunaan aplikasi e-faktur versi 3.0.

Kelemahan aplikasi e-faktur versi 3.0 yang dijelaskan oleh informan adalah mengenai kelancaran akses aplikasi e-faktur versi 3.0 menjelang mendekati tanggal jatuh tempo laporan SPT Masa PPN. Aplikasi e-faktur versi 3.0 merupakan aplikasi yang berbasis web sehingga diharapkan aplikasi dapat dengan mudah diakses dari manapun. Namun kendala yang dialami oleh informan, aplikasi e-faktur versi 3.0 terkadang tidak dapat diakses terutama mendekati tanggal deadline pelaporan SPT Masa PPN. Saat aplikasi e-faktur versi 3.0 mengalami gangguan, maka PKP yang belum melaporkan SPT Masa PPN pada masa tersebut akan terkena sanksi administrasi atas keterlambatan pelaporan SPT Masa PPN.

\section{SIMPULAN}

Penelitian ini menemukan bahwa aplikasi e-faktur versi 3.0 dapat diterima oleh pengguna yakni PKP Pilot Projecting aplikasi e-faktur versi 3.0 yang terdaftar pada KPP Pratama Badung Utara. Penerimaan pengguna aplikasi e-faktur versi 3.0 memenuhi unsur dari TAM yakni persepsi kegunaan dan persepsi kemudahan. Persepsi kegunaan dari aplikasi e-faktur versi 3.0 yang ditemukan dalam penelitian ini adalah mempercepat pekerjaan, meningkatkan performa, meningkatkan produktifitas, efektifitas, mempermudah pekerjaan, bermanfaat dan membantu. Persepsi kemudahan dari aplikasi e-faktur versi 3.0 menurut pengguna mudah dipelajari, dapat dikontrol, jelas dan dapat dipahami, fleksibel, mudah mahir, mudah digunakan, kendala cepat teratasi, dan intensitas pemakaian. 
Persepsi pengguna dapat menjelaskan sikap terhadap penggunaan sehingga pada akhirnya menjelaskan minat penggunaan aplikasi e-faktur versi 3.0. Penelitian ini memiliki implikasi bahwa implementasi aplikasi e-faktur versi 3.0 sudah tepat karena berdasarkan temuan dalam penelitian ini sebagian besar pengguna merasa sangat terbantu dengan adanya aplikasi e-faktur versi 3.0.

Keterbatasan penelitian, metode pengumpulan data melalui wawancara Zoom Meeting, karena adanya pandemi Covid 19. Wawancara yang dilakukan terhadap informan melalui Zoom Meeting tidak secara bebas dapat menangkap informasi dan ekspresi yang ditunjukkan oleh informan. Gangguan koneksi jaringan yang tidak stabil juga menjadi kendala dalam pelaksanaan wawancara.

TAM telah mengalami perkembangan dimana diantaranya memasukkan unsur motivasi dalam pembentukan persepsi pengguna. Unsur motivasi baik merupakan motivasi intrinsik maupun motivasi ekstrinsik menjelaskan perilaku individu dalam mengadopsi suatu teknologi informasi baru. Saran bagi penelitian selanjutnya dapat mengintegrasikan TAM dengan teori Motivational Acceptance Model yang berguna untuk lebih mengetahui bagaimana persepsi pengguna terhadap suatu sistem informasi terbentuk, seperti menambahkan self efficacy perception dan motivation perception.

Rekomendasi bagi pengambil kebijakan pada Direktorat Jenderal Pajak berdasarkan temuan dalam penelitian ini adalah menu prepopulated yang di generate by system pada aplikasi e-faktur versi 3.0 dapat diperluas tidak hanya menyangkut pajak masukan dan PIB. Pengguna merekomendasikan agar aplikasi efaktur versi 3.0 juga mengakomodasi prepopulated retur pembelian. Hal ini akan semakin memudahkan pengguna karena data retur pembelian sudah tersedia secara sistem.

\section{REFERENSI}

Amer, A.-A., Ahmad, A.-A., \& Jo, S. (2013). Exploring Students Acceptance of Elearning Using Technology Acceptance
Model in Jordanian Universities. International Journal of Education and Development Using Information and Communication Technology, 9(2), 4-18. http://ijedict.dec.uwi.edu/viewarticle.ph $\mathrm{p}$ ?id=1617

Bahari, A., Rahman Mus, A., \& Mursalim, M. (2020). Perceived Ease, Benefits and Perceived Enjoyment of E-Invoice User Interests. Point of View Research Accounting and Auditing, 1(3), 33-42. https://doi.org/10.47090/povraa.v1i3.28

Beldad, A. D., \& Hegner, S. M. (2018). Expanding the Technology Acceptance Model with the Inclusion of Trust, Social Influence, and Health Valuation to Determine the Predictors of German Users' Willingness to Continue using a Fitness App: A Structural Equation Modeling Approach. International Journal of Human-Computer Interaction, 34(9), 882893.

https://doi.org/10.1080/10447318.2017.1 403220

Bhuasiri, W., Zo, H., Lee, H., \& Ciganek, A. P. (2016). User Acceptance of e-government Services: Examining an e-tax Filing and Payment System in Thailand. Information Technology for Development, 22(4), 672-695. https://doi.org/10.1080/02681102.2016.1 173001

Bundot, G. Y., Yunos, J. M., \& ... (2017). Technology Acceptance Model Of Intention To Use ICT By Academics In Nigerian Higher Education. Online Journal for TVET ..., 2(1), 3-7. https://publisher.uthm.edu.my/ojs/inde x.php/oj-tp/article/view/4771

Chen, C. F., Xu, X., \& Arpan, L. (2017). Between the technology acceptance model and sustainable energy technology acceptance model: Investigating smart meter acceptance in the United States. Energy Research and Social Science, 25(Energy Res. Soc.

Sci.), 93-104. 
https://doi.org/10.1016/j.erss.2016.12.01 1

Granić, A., \& Marangunić, N. (2019). Technology acceptance model in educational context: A systematic literature review. British Journal of Educational Technology, 50(5), 2572-2593. https://doi.org/10.1111/bjet.12864

Kemp, A., Palmer, E., \& Strelan, P. (2019). A taxonomy of factors affecting attitudes towards educational technologies for use with technology acceptance models. British Journal of Educational Technology, 50(5), 2394-2413. https://doi.org/10.1111/bjet.12833

Koul, S., \& Eydgahi, A. (2018). Utilizing technology acceptance model (Tam) for driverless car technology adoption. Journal of Technology Management and Innovation, 13(4), 37-46. https://doi.org/10.4067/S071827242018000400037

Liao, S., Hong, J.-C., Wen, M.-H., Pan, Y.-C., \& Wu, Y.-. (2018). Applying Technology Acceptance Model (TAM) to explore Users' Behavioral Intention to Adopt a Performance Assessment System for Ebook Production. EURASIA Journal of Mathematics, Science and Technology Education, 14(10), 1-12. https://doi.org/10.29333/ ejmste/93575

Ma, Y. J., Gam, H. J., \& Banning, J. (2017). Perceived ease of use and usefulness of sustainability labels on apparel products: application of the technology acceptance model. Fashion and Textiles, 4(1), 1-20. https://doi.org/10.1186/s40691-0170093-1

Mlekus, L., Bentler, D., Paruzel, A., KatoBeiderwieden, A. L., \& Maier, G. W. (2020). How to raise technology acceptance: user experience characteristics as technologyinherent determinants. Gruppe. Interaktion. Organisation. Zeitschrift Fur Angewandte
Organisationspsychologie, 51(3), 273-283. https://doi.org/10.1007/s11612-02000529-7

Natasya, N., Tandililing, E. M., Angelus, M., \& Kevin, K. (2019). Tax E-Filing System Acceptance Level on the Taxation Compliance: An Application of the UTAUT Approach. The Winners, 20(1), 33. https://doi.org/10.21512/tw.v20i1.5572

Nguyen, A. H., Nguyen, T. P., \& Dang, G. T. T. (2020). Determinants of E-invoice adoption: Empirical evidence from Vietnam. Journal of Asian Finance, Economics and Business, 7(7), 311-321. https://doi.org/10.13106/jafeb.2020.vol7. no7.311

Perangin-angin, W. A., Respati, A. D., \& Kusumawati, M. D. (2016). Pengaruh Perceived Usefulness Dan Perceived Ease of Use Terhadap Attitude Toward Using E-Faktur. Jurnal Riset Ekonomi Dan Manajemen, $\quad$ 16(2), 307. https://doi.org/10.17970/jrem.16.160201 $0 . i d$

Phua, P. L., Wong, S. L., \& Abu, R. (2012). Factors Influencing the Behavioural Intention to use the Internet as a TeachingLearning Tool in Home Economics. Procedia - Social and Behavioral Sciences, 59, 180-187. https://doi.org/10.1016/j.sbspro.2012.09. 263

Ratna, P. A., \& Mehra, S. (2015). Exploring the acceptance for e-learning using technology acceptance model among university students in India. International Journal of Process Management and Benchmarking, 5(2), 194-210.

https://doi.org/10.1504/IJPMB.2015.068 667

Ratsidyaningtyas, azzilizza febri., Kartika, \& Andriana. (2016). Analisis Penerimaan eFaktur Melalui Pendekatan Technology Acceptance Model pada Pengusaha Kena 
Pajak ( Studi Empiris pada Pengusaha Kena Pajak yang Terdaftar Menggunakan e- Faktur Pada Kantor Pelayanan Pajak Pratama Jember ) Receptions Analyze of eInvoi. SRA-Economic and Business Article, 1, 7.

http:// repository.unej.ac.id/handle/1234 $56789 / 74340$

Rodrigues Pinho, J. C. M., \& Soares, A. M. (2011). Examining the technology acceptance model in the adoption of social networks. Journal of Research in Interactive Marketing, 5(October 2015), 116-129. https://doi.org/10.1108/17505931111187 767

Sangkaew, P., Jago, L., \& Gkritzali, A. (2019). Adapting the technology acceptance model (tam) for business events: The event organizer perspectiv. Event Management, 23(6), 773-788. https://doi.org/10.3727/152599519X1550 6259855832

Siegel, D., Acharya, P., \& Sivo, S. (2017). Extending the Technology Acceptance Model to Improve Usage \& Decrease Resistance toward a New Technology by Faculty in Higher Education. Journal of Technology Studies, 43(2), 58-69. https://doi.org/10.21061/jots.v43i2.a.1

Sijabat, R. (2020). Analysis of e-government services: A study of the adoption of electronic tax filing in Indonesia. Jurnal Ilmu Sosial Dan Ilmu Politik, 23(3), 179-197. https://doi.org/10.22146/jsp.52770

Soneka, P. N., \& Phiri, J. (2019). A Model for Improving E-Tax Systems Adoption in Rural Zambia Based on the TAM Model. Open Journal of Business and Management, 07(02),

908-918. https://doi.org/10.4236/ojbm.2019.72062

Taherdoost, H. (2018). A review of technology acceptance and adoption models and theories. Procedia Manufacturing, 22, 960967.

https://doi.org/10.1016/j.promfg.2018.03 .137

Yasa, N. N. K., Ratnaningrum, L. P. R. A., \& Sukaatmadja, P. G. (2014). the Application of Technology Acceptance Model on Internet Banking Users in the City of Denpasar. Jurnal Manajemen Dan Kewirausahaan, 16(2), 93-102. https://doi.org/10.9744/jmk.16.2.93-102 